\title{
LEGAL FRAMEWORK AND MECHANISM OF MARINE FISHERIES SUBSIDIES IN THE ASPECTS OF INTERNATIONAL TRADE AND SUSTAINABLE DEVELOPMENT
}

\author{
Adijaya Yusuf,* Melda Kamil Ariadno, ${ }^{* *}$ Arie Afriansyah***
}

\begin{abstract}
*Senior Lecturer, Faculty of Law, Universitas Indonesia.
**Professor of Law, Faculty of Law, Universitas Indonesia.

***Lecturer, Faculty of Law, Universitas Indonesia.
\end{abstract}

\section{Article Info}

Received : 2 April 2015 | Received in revised form : 22 December 2015 | Accepted : 24 December 2015 Corresponding author's e-mail : adijayayusuf@yahoo.com/meldakamil@gmail.com/arieafriansyah@ gmail.com.

\begin{abstract}
Issues in fisheries have been regulated in various international conventions. The United Nations Convention on the Law of the Sea 1982 (UNCLOS 1982) has built a regime in the field of conservation and management of fishery resources based upon maritime zones or fish species that exist and available in this zone. However, UNCLOS 1982 only focuses on the issue of fisheries in the Exclusive Economic Zone (EEZ) and the high seas, thus it was not sufficient to overcome the problems of high frequent of fishing in maritime zones which are fully subject to the jurisdiction of coastal states, such as in the Inland waters, archipelagic waters and the Territorial Sea. This article aims to examine the legal framework and mechanisms of fisheries subsidies in the aspects of trade and sustainable development. In this article, discussion would carried out in order to examinethe legal framework and mechanisms of marine fisheries subsidies that are implemented with the principles of fair-trade and sustainable development, both in the international level, as well as in the national level. Thus, this research is expected to be able to bridge the interests of developed countries and developing countries, especially Indonesia, in order to achieve fair trade in the field of fisheries and resource utilization of sustainable fisheries.
\end{abstract}

Keywords: fisheries subsidies, WTO, trade, sustainable development.

\begin{abstract}
Abstrak
Masalah perikanan sudah diatur dalam berbagai konvensi internasional. The United Nations Convention on the Law of the Sea 1982 (UNCLOS 1982) membangun rezim di bidang konservasi dan pengelolaan sumber daya perikanan berdasarkan zona maritim atau jenis ikan yang ada dan tersedia di zona ini. Namun, UNCLOS 1982 hanya focus pada isu perikanan di Zona Ekonomi Eksklusif (ZEE) dan laut bebas, sehingga tidak cukup untuk mengatasi masalah penangkapan ikan yang tinggi di zona maritim yang tunduk sepenuhnya pada yurisdiksi Negara pantai, seperti di Perairan Pedalaman, Perairan Kepulauan dan Laut Teritorial. Riset ini akan meneliti kerangka hokum dan mekanisme subsidi perikanan dalam aspek perdagangan dan pembangunan berkelanjutan. Oleh karena itu, dalam riset ini akan dikaji dan diteliti kerangka hokum dan mekanisme subsidi perikanan laut yang dilaksanakan dengan prinsip-prinsip fair trade dan pembangunan berkelanjutan, baik di tingkat internasional, maupun di tingkat nasional. Dengan demikian, riset ini diharapkan akan mampu menjembatani kepentingan Negara maju dan Negara berkembang, khususnya Indonesia, demi tercapainya fair trade dalam bidang perikanan dan pemanfaatan sumber daya perikanan yang berkelanjutan.
\end{abstract}

Kata Kunci: subsidi perikanan, WTO, perdagangan, pembangunan berkelanjutan. 


\section{Introduction}

Fisheries are almost invariably used as a source of protein and play an important role for food security and the economy. There are some factors that contribute to the expansion of fishing have been initiated since the 11th century and continue to grow rapidly to this day; aquantity of reduction in marine fish and freshwater fish, a rapid growth of human population, the increased trade between countries and the introduction of new technologies. These circumstances gave rise to concerns that food security would be threatened because fishery resources would run out due to overexploitation. ${ }^{1}$ Fishing vessels are equipped with technology that is able to maximize the catch can not be separated from government subsidies in the field of marine fisheries. Weak protection of the marine environment also contributed to the over-exploitation that is conducted by fishing vessels with adequate technology. The issue of fisheries has been regulated in various international conventions.The United Nations Convention on the Law of the Sea 1982 (UNCLOS 1982) has builta regime in the field of conservation and management of fishery resources based upon maritime zones or fish species that exist and available in this zone. However, UNCLOS 1982 only focus on the issue of fisheries in the Exclusive Economic Zone (EEZ) and the high seas, so it was not sufficient to overcome the problems of high frequent of fishing in maritime zones which are fully subject to the jurisdiction of coastal states, such as in the Inland waters, archipelagic waters and the Sea Territories.

Meanwhile, both NGOs and IGOs have raised the issue of fisheries subsidies by some developed and developing countries to come together in a new coalition, known as the "Friends of Fish" (FoF), to lead the effort in bringing the issue of fisheries subsidies to the WTO negotiating agenda. In 2001, these efforts were realized when the WTO Ministerial Members at the WTO Ministers' meeting held in Doha, Qataragreed to conduct negotiations on clarifying and improving WTO disciplines on fisheries subsidies "in the context of" negotiations on "WTO Rules.'. Hence, negotiations on fisheries subsidies organized and became one of the core points of the agenda of the WTO Negotiating Group on Rules in the Doha Round.

The growing of international diplomatic pressure for the sake of solid results in the fisheries subsidies negotiations has resulted negotiations that are well developed in the first years. In 2002, the Heads of State gathered at the World Summit, Sustainable Development in Johannesburg, South Africa, requested Member States to eliminate government fisheries subsidies that are detrimental through the new effective WTO rules. In 2004, a large-scale UNEP workshop was held in Geneva, provided a turning point - the movement of the negotiation of the question "whether" to the question "how" the fisheries subsidies can be improved through the WTO rules. ${ }^{3}$ However, to this day, discussion about the fisheries subsidies in the WTO Doha Round is reaching a deadlock because of the differences in the interests of developed and developing countries.

1 An Palma Marry, et.al., Legal Aspects of Sustainable Development, Promoting Sustainable Fisheries, The International Legal \& Policy Framework to Combat Illegal, Unreported \& Unregulated Fishing (Leiden: Martinus Nijhoff, 2010), p. 1.

2 “' Friends of Fish' Press for Negotiations on Fisheries Subsidies at WTO," http://www.ictsd.org/ bridges-news/biores/news/friends-of-fish-press-for-negotiations-on-fisheries-subsides-at-wto, accessed on 15 March 2015.

${ }^{3}$ UNEP, "Analyzing the resource impact of Fisheries Subsidies: A Matrix Approach," http://www.unep. ch/etb/publications/fishiersubsidiesenvironment/anaresimpfishsubs.pdf, accessed on 15 March 2015. 
Indonesia as a developing as well as an archipelagic country with abundant marine resources has an interest in protecting the marine resources for future generations as well as improving the living standards of its people. For this purpose, the government of Indonesia creates policies in the field of fisheries which, if observed, have the potential to be regarded as subsidies in the fisheries sector.

Based on the above, it is necessary to study the fundamental legal issues of the implementation of the subsidies in the fisheries sector in Indonesia towards the implementation of fair trade and sustainability of the marine environment. It should also explain the legal framework and mechanisms of fisheries subsidies run in Indonesia and international view from the aspect of international trade and sustainable development.This paper also seeks to provide national strategies policy that can improve the competitiveness of the domestic fishery commodities to foreign fishery commodities in domestic and international markets related to the implementation of fisheries subsidies.

\section{Fisheries Subsidies by State}

Regarding to the fisheries subsidies, the analysis of the problem can be retrieved from two perspectives, namely the perspective of sustainable development and the perspective of trade. In the first perspective, fisheries subsidies increase the capacity of fishing that exceeds the natural ability to "recovery" and destroying the ecological balance resulting in a decrease in fishery resources. This situation would be detrimental to the fishermen since there will be a decrease in fishery resources and, in the long term, reduce the number of fisheries resources. The second perspective views the fisheries subsidies that provided by the State resulting in an"unfair competitive advantage". These subsidies create real barriers to trade as a result of the low price of domestic fish production due to subsidies on fisheries sector. Attempts to regulate the fisheries subsidies as part of the Uruguay Round Agreement on Agriculture has failed to meet consensus. ${ }^{4}$

Subsidies are considered to beadverseas it affects trade. In general, the impact of subsidies on tradec an be classified as follows:

a) Increase the export of subsidized productsto the importing country.

b) Increase the country's subsidized export to third countries, resulting in a direct impact on other countries' exports to the country.

c) Inhibits imports to the State that apply subsidies

These three impacts inhibit international trade liberalization. The actual consequences of fisheries subsidies depend on how subsidies are implemented and how laws and regulations govern the subsidy. Subsidies may reduce the efficiency of the allocation of natural resources and international trade order. Normally, without effective limitation of the number of catches, fisheries subsidies can result in in an increase in the supply of fish to the domestic market and the world market, thereby affecting trade flows and price. ${ }^{5}$

In the aspect of environment, fisheries subsidies could cause overall damage to the ecosystem and biodiversity. Excessive explorationas a result of subsidized fisheries could reduce and alter ecological link on predator or prey in marine life that could

\footnotetext{
${ }^{4}$ Chen-Ju Chen, Fisheries Subsidies under International Law (London: Springer, 2010), p. 22.
}

${ }^{5}$ Ibid., p. 11 
disrupt ecosystems.The loss of one of these components could result in irreversible or not restored.

\section{Fisheries and Indonesia}

Indonesia is the largest archipelagic state in the world with 17,504 islands and coastline that reaches $95181 \mathrm{~km} .{ }^{6}$ Sixty-five per cent of the total 467 districts / cities in Indonesia are in the coastal area. ${ }^{7}$ In 2010 the population of Indonesia has reached more than 237 million people, of which more than $80 \%$ live in coastal areas.

Indonesia has a rich marine biodiversity because of its strategic location. Coral reefs reached the total area of $50875 \mathrm{~km}^{2}$, or approximately $18 \%$ of the total area of the world's reefs. Most coral reefs are located in the eastern part of Indonesia, the region commonly known as the Coral Triangle. Coral reefs in the Coral Triangle are one of the richest biodiversity in the world, home to about 590 species of hard coral.

Coral reefs provide a major contribution to the fishing sector by providing separated area for weaning process, food and shelter for variety of sea creatures. In addition, Indonesia also has a fairly wide of mangrove distribution. This results in an abundant of marine biodiversity.

Indonesia's abundant marine resources, and easy access to the territory of the islands water, lead to the development of the fishing industry. Today, Indonesia is the world's third largest fisheries producer after China and Peru. However, when the Indonesian fisheries production increased, Indonesia suffered on a decline due to the threat of a double crisis from the marine ecosystem degradation and overfishing. Indonesia is the most at riskof decline. According to research in 2012, compared with 27 other fish producing countries, Indonesian fisheries are the most vulnerable based on management of coral reefs indicator, fisheries situation and food security.

Some fisheries management areas in Indonesia have been facing symptoms of excessive fish exploitation on some important commodities such as large pelagic, small pelagic, shrimp and demersal fish.Small fisheries are most likely to be affected by such condition. The cost to be covered by fishermen becomes increasingly high to cover fuel. This is needed given the location of fishing became more distant towards the open sea.

Moreover, scarcity can also be seen from the decrease in the size of the fish, drop in the number of capture and the loss of some species which was once the main catch of fishermen. In addition, Indonesian fisheries also face threats such as illegal fishing and illegal use of equipment for fishing. ${ }^{8}$

Given this increasingly unsettling condition, Indonesia began to change the direction of its fisheries policy. The government directs its policies to make Indonesia as the largest, leading, value-added and competitive marine and fisheries commodities' producer. These goals are manifested through productivity improvement, value added and welfare, improvement in competitiveness and market-oriented modernization, as well as self-sufficiency and sustainable management of marine and fisheries, particularly upstream and downstream environmentally friendly integration

Fisheries industrialization which has begun in 2012 is also a strategy to accelerate

\footnotetext{
${ }^{6}$ Akhmad Solihin, et.al., Laut Indonesia Dalam Krisis (Green Peace, 2013), p.1.

${ }^{7}$ Ibid.

${ }^{8}$ Ibid.
} 
the development of marine and fisheries. The implementation of marine and fisheries industrialization is strengthened by the issuance of Ministry Decree of Maritime and Fisheries Affairs of the Republic of Indonesia No. PER.27 / MEN / 2012 dated December 27, 2012 on General Guidelines for Maritime Affairs and Fisheries Industrialization.

The following are the principles of industrialization:

1. Increase the value and competitiveness of domestic fishermen to be able to compete with export products and fulfil domestic needs.

2. Modernization and improvement of the efficiency of the production system, both upstream and downstream.

3. Strengthen the marine and fisheries industry, by increasing the number, capacity, and quality of marine and fisheries industry and fostering relationships between business entities and the industry at all stages of the value chain to strengthen the structure of the marine industry and fisheries.

4. Commodity, region, and regional management system based, with the concentration of which is focused on selected commodities, the potential of the region and the management of potential production centres in accordance with the prospect of future growth.

5. Sustainable, which carries the principle of balance between the natural resource exploitation and long-term environmental protection (sustainable development).

6. Social transformation, with efforts to change the mindset and behaviour patterns of modern society.

\section{Blue Economy and Fisheries}

Along with the industrialization of marine and fisheries, the application of the concept of blue economy (economic blue) in the development of marine was also promoted. Gunter Pauli introduced the Concept of Blue economy in his book "The Blue Economy" (2010). This economic conception is based on creations and innovations to leverage the potential of existing resources efficiently and sustainably. The principles of the concept of blue economyinclude:

1. Efficient use of natural resources;

2. Zero waste;

3. Creating social inclusiveness;

4. Sustainable production cycle system and;

5. Development of innovation and technology adaptation.

In the context of the implementation of industrialization and the Blue Economy, the system adopts the marine and fisheries sector development system using the area-based Minapolitan concept.Minapolitan derived from the word 'mina' which means fish and 'politan' which is defined as polis or city, thus Minapolitan was interpreted as a fishing town. The development of Minapolitan concept was intended to accelerate economic development of marine and fisheries management with a fastgrowing areas systems approach just like a city. With the Minapolitan concept, the development of marine and fisheries sector is expected to accelerate.

Minapolitan concept itself has two main elements; firstly, Minapolitan as a concept to develop the area-based marine and fisheries sector andsecondly, Minapolitan as 
a leading economic region with marine and fishery products as its main products. In summary,Minapolitan can be defined as the concept of Economic Development of Marine and Fisheries with marine and fisheries-based, area-based approaches and regional management system based on the principle of integration, efficiency and quality as well as high acceleration.Whereas Minapolitan Zone is an economic area of marine-and-fisheries-based consist of centers of production and trade in services, residential and other activities that are interrelated.

In essence, there are three main programs established by the government to realize the above objectives including: ${ }^{9}$

a) By building the economic zone fisheries, ranging from pre-production to postproduction stages which was conducted with an environmental friendly manners and the principle of blue economy:

1. Penyejahteraan Kehidupan Nelayan (PKN). PKN is one of government aid programs outside the assistance in the field of fisheries, which aims to improve the lives of the fishermen.This program includes cheap electricity program and fund or facilitation assistance of materials to improve the feasibility of residence.

2. Minapolitan. Minapolitan is also a government industrialization program in the field of fisheries that aims to encourage and improve the fishermen cruising range toward the open sea, by enlarging the fleet owned by fishermen. In contrast to other types of programs, Minapolitan program involves the role of various ministries, with the fisheries industry as the central core, ranging from pre-production, production to post-production, including processing and marketing.

3. ECOPORT. ECOPORT is an environmental friendly industrialization program launched by the government. The concept that carried by ECOPORT program is that all the energy and nutrients that are used in all stages of pre-production, production and post-production of fisheries product will be used to avoid waste. This was conducted to reduce the number of waste or trash, to prevent pollution, water pollution and air pollution.

4. Introduce and educate fishermen about the existence of the banking system, insurance and consortiums in Indonesia, through various government programs addressed for fishing communities, such as PUMP (Pengembangan Usaha Mina Pedesaan) program.

Marine resources in Indonesia are very abundant, however it is not proportional to the level of welfare of fishermen asthe majority of Indonesian people's livelihoods. Data of the coordinator of KIARA program mentioned the amount of poor fishermen in the year 2012 amounted to 7.87 million people $(25.15 \%)$ of the national poverty. ${ }^{10}$ Moreover, from the aspect of technology, Indonesian fishermen are traditional fishermen, it can be seen from the 2006 data whereby the engineless fleet of fishing boats amounted to 244190 units (43.92\% of 555 950),outboard motors amounted to 165.430 unit $(29,76 \%)$ motor boat body amounted to $146.330(26,32 \%) .{ }^{11}$ Based on the data, it can be seen that the majority of Indonesian fishing fleet are small-scale fisherieswhich can only catch fish around the coast. Therefore, the State is obliged to

${ }^{9}$ Based on the interview with the Directorate General of Capture Fisheries Ministry of Marine Affairs and Fisheries of the Republic of Indonesia, dated October 7, 2013

${ }^{10}$ See Maritime Magazine Edition 21 Year II (2012): 63.

11 Draft of Academic Paper on Amendment Act No. 31 of 2004 Regarding Fisheries, p. 27. 
improve the welfare of fishermen.

\section{Current Assistance Program Conducted by Indonesia Government ${ }^{12}$}

Government efforts to alleviate poverty of the fishermen were conducted through government programs as have beendescribed above. To achieve the objectives of the government programs, capital for the fishermen to improve fisheries management is needed. Hence, the government establishes assistance programs for fishermen in order to improve their welfare.The assistance is done with the introduction of banking products to the fishermen so that fishermen can get a loan to renew and improve their fishing fleet. In addition, fishermen introduced to models of cooperation with entrepreneurs in developing the fishing fleet.

One of the programs launched by the government in to stimulate fishermen productivity is through Pengembangan Usaha Mina Pedesaan (PUMP). PUMP program is intended to encourage and nurture the entrepreneurial spirit of small fishermen. By this program, the fishermen are required to form a Joint Business Group (Kelompok Usaha Bersama/KUB) that consists of 10-15 people per group. The group will then prepare a plan of work or proposal containing one year of work plan for the future, along with the details of the funds needed and targeted use of these funds. If the business plan is approved by the department, then through a bank, KUB which business plan has been approved willreceive 100 million rupiah per group to finance its operations, which will be managed independently by each KUB. After a certain period of time, the funds must be returned to the bank, and then rotated back to the other groups.

Other government assistance programs whichis also intended to encourage business activities of Indonesian fishermen is through INKAMINA program. INKAMINA is a program of procurement of $30 \mathrm{GT}$ ships, which aims to increase the fishermen cruising range. In this respect, the fishermen also have to make Business Group (KUB) and submit a business plan.

This is similar to the Bantuan Langsung Masyarakat (BLM), which is listed in the Marine and Fisheries Ministerial Decree Number 22Year 2011 on Guidelines for Distribution of Direct Aid Society of Marine Affairs and Fisheries through Funding Sources State Budget. Bantuan Langsung Masyarakat (BLM) in the maritime affairs and fisheries sector is a program of assistance which selectively and not constantly, provided to the public or community organizations including non-governmental organizations in education sector, either in the form of goods, money or services that aims to improve the welfare of the marine and fisheries communities, hereinafter referred to as the BLM-KP. For fishermen, this program is intended to be limited only for the fishing vessel under 60 GT.For assistance outside business activities of fishermen, the government also provides Penyejahteraan Kehidupan Nelayan (PKN) program which is devoted to the improvement of the living standards of fishermen, as seen from the increase in the quality of residence, supply of electricity, water and so forth.

The fishermen communities in Nusantara Fishing Port of Pelabuhan Ratu receive two forms of government aid programs, beyond some other subsidized assistance, namely Pengembangan Usaha Mina Pedesaan (PUMP) program and INKAMINA program. PUMP is a business development program financial assistance amounting

\footnotetext{
12 Based on research conducted in "Pelabuhan Ratu" and "Pelabuhan Muara Baru” in 2013.
} 
to 100 million rupiah given to a Business Group (KUB) of fishermen after submitting a business plan proposal.The 100 million rupiah funds given to the KUB can be managed independently by fishermen who are members of the KUB, in accordance with the work plan, but with the provision that only $20 \%$ of all funds can be used to meet the operational needs (such as gasoline and food supply), and the rest should be used for the fulfilment of facilities (such as ship repair, purchase of nets, fishing gear, and so on). This PUMP funds are directly transferred to the group's bank account after the group business plan is approved.

In addition to PUMP and INKAMINA programs, fishing communities in Pelabuhan Ratu also receive subsidies in several fields, such as subsidized fuel (fuel oil), as well as subsidies in the Penyejahteraan Kehidupan Nelayan (PKN) program. PKN is focused on improving the living standards outside fishing activities, such as improving the quality of residence and supply cheap electricity. For cheap electricity-saving program, in 2012, the government has been providing cheap electricity for 100 homes and increased to 318 homes in 2013. In terms of cheap electricity-saving program, each home will be given subsidies in the form of 3 lights and 2 sockets free, and to the rest will be borne by the respective families. Also various other forms of subsidies such as health training, but it does not involve fisheries department.

Unlike the Nusantara Fishing Port in Pelabuhan Ratu, Muara Baru Port is a Nusantara fishing port, it means that the ships anchored in the Muara Baru Port are the 60 GT sized vessels, and it is in the form of a limited company (Perseroan Terbatas), so based on the interviews that have been conducted, there are no form of subsidies received by this community as received by the fishing community in Nusantara fishing Port at Pelabuhan Ratu who still receive assistance programs such as PUMP, INKAMINA and Penyejahteraan Kehidupan Nelayan (PKN).

The only subsidy received by the fishermen who conduct business activities in the Port of Muara Baru are subsidized fuel oil (BBM), amounted of 25 kiloliter per one boat for one month. It is under the consideration that the ships which conducting business in the Port of Muara Baru is a fairly large ships with a size of over 60 GT, so the power supply needed for one vessel are $350 \mathrm{PK}$, then with such calculation, the average subsidies received by fishermen in Muara Baru are 5 liters / hour, and this amount is only enough to supply one main engine. While in one vessel, there is one main engine for propulsion and two additional machines are useful for providing power supply for lamps and cold storages. Each additional engine can reach $120 \mathrm{PK}$, and do not get subsidies; fishermen must meet their own needs of fuel for their other additional machines.

However beside the fuel subsidies, the fishermen in Muara Baru no longer receive other form of subsidies such as PUMP and INKAMINA, given its business activities have already in the form of limited company or individual, it is no longer a in the form of business group like KUB in Pelabuhan Ratu.

As stated in welfarestate theory, Indonesia as a country is obliged to improve the welfare of fishermen which constitute the majority of livelihood of its people. Thus, this is the basis for Indonesia to establish subsidies program.

However, subsidies and assistance programs provided by the government is a program aimed at small fishermen, with the size of the vessel under 60 GT, while there are no subsidies which was given for vessels with sizes above $60 \mathrm{GT}$, in any form, except for subsidized fuel. Assistance program created by the government aims to encourage small entrepreneurial of archipelago fishermen to be able to expand its 
business, and thus will ultimately be able to participate in the national economy. In addition, Indonesian fishing vessels which receive subsidies or other assistancedo not violate international regulations as the prohibited subsidies are subsidies or any form of assistance given to vessels over $120 \mathrm{GT}$.

Thus, subsidy programs or national aids given by the government to the fishermen are not prohibited by international guidelines. Given that the targets of subsidies or national aid programs of the government are fishing communities residing in rural areas or small fishermen, not the fishermen in the form of large capital corporation.

The programs launched by the government above still require improvement from various sides. Examples are as follows: ${ }^{13}$

1. Programs relating to the provision of government aid programs, like Pengembangan Usaha Mina Pedesaan program (PUMP), INKAMINA and Peningkatan Kehidupan Nelayan (PKN). Notes for this program are as follows:

a. Systems and mechanisms that are not uniform;

For example the implementation of PUMP between Pelabuhan Ratu and Muara Baru are not uniform. Based on the interview conducted in Muara Baru, it was stated that PUMP funds are temporary loan funds which must be returned to the bank after a certain period of time so it can be utilized by another Business Group (KUB).

While the results of an interview in Pelabuhan Ratu, stated that the PUMP funds received by the fishing community are the group savings and it becomes an endowment among the KUB. KUB has no obligation to repay the funds to the bank and there is no set period of time (an unlimited period).

b. The systems and control mechanisms still need to be improved; and

The existing control mechanisms are still not sufficient to accommodate all forms of violations and deviations. For example, in Pelabuhan Ratu, fishermen who receive assistance program such as PUMP or INKAMINA, the department took no action if they are unable to pay back the funds they have received, or if they are unable to pay off the ship that they obtained. In case of any problems on these funds, then it is the responsibility of the respective groups. Government or agency only act as far as to provide counselling and training. So it is probable that these funds are not managed properly.

c. Lack of fund and an uneven distribution.

Based on the data obtained through an interview, from approximately 165169 KUB registered, only about 9 KUB (2011) which obtain the PUMP funds, 20 KUB in 2012, and decreased to 17 KUB in 2013. And with a repayment period which takes 2-3 years, the revolving funds are considered to be very slow, and another KUB have to wait a long time to be able to propose work plan to obtain PUMP funds. This is caused by the limited funds provided by the central government.

2. The program relating to the sustainable development paradigm. Notes for this program are as follows: ${ }^{14}$

a. System and control mechanisms have not been sufficient; and

Although the Directorate of Fish Resources of Ministry of Maritime and

${ }^{13}$ Based on the final report of the authors' research in 2013.

14 Ibid. 
Fisheries Affairs has issued a list containing three groups of fish, it is difficult to continuously monitor and oversee the fishermen who have a bad faith or low awareness, for example, it is very difficult to prohibit fishermen who catch fish which are included into the red group, or restrict fishermen in catching fish that are already included in the yellow group. Plus the existence of fishing gear called Bagan in PelabuhanRatu, which attracts all the fish that are phototaxis, regardless of the type and species, which has yet to be resolved.

b. Lack of local wisdom and awareness.

While the government continues to hold training and counselling, as well as dissemination to the fishermen about the current condition of Indonesian fisheries, and the importance to continue to preserve the ocean, yet, local knowledge in these two areas have not gotten to the point where fishermen have sufficient awareness levels to adjust their fishing patterns with current condition of Indonesian fisheries, and the willingness are not sufficient to begin promoting the sustainable development paradigm in the field of fisheries.

\section{Fisheries Policy and International Trade}

It has been suggested that governments around the world continue to provide billions, and by some account tens of billions, of dollars in subsidies to the fisheries sector. ${ }^{15}$ There were numbers of negotiations under WTO to clarify and improve WTO disciplines on fisheries subsidies and growing concerns on strengthening those disciplines, including through a prohibition of certain forms of fisheries subsidies that contribute to overcapacity and overfishing. An informal grouping of members calling themselves the "Friends of Fish" (including Argentina, Australia, Chile, Colombia, New Zealand, Norway, Iceland, Pakistan, Peru and the United States) ${ }^{16}$ claimed that subsidies to the fisheries sector have led to over-capacity and overfishing. Japan, the Rep. of Korea and Chinese Taipei, on the other hand, have expressed scepticism over the link between subsidies and over-fishing. On the other parts, many developing countries are asking for flexibility in granting subsidies to their fisheries sectors. ${ }^{17}$

Indonesia has so far kept trying to implement international regulations related to sustainable fisheries, but this should not necessarily be implemented because they have to adjust to the country's ability to implement it. But so far Indonesia continues to strive to as determined towards international regulations. This was also done due by the demand from the importing country.

Regulations that have been implemented are also adjusted, so that there are regulations, which have fully been implemented as has been regulated in international level, some are being simplified and reserved, but there are also regulations that have not been consistent to international regulations. The following provisions have

${ }^{15}$ WTO, "Introduction to fisheries subsidies in the WTO," https://www.wto.org/english/tratop e/ rulesneg e/fish e/fish intro e.htm, accessed 12 June 2014.

${ }^{16}$ US' practices on fisheries practices can be read from Renee Sharp and U. Rashid Sumaila, "Quantification of US Marine Fisheries Subsidies," North American Journal of Fisheries Management 29 No. 1 (2009): 18-32.

17 For more discussion, see Margaret A. Young, "Fragmentation or Interaction: The WTO, Fisheries Subsidies, and International Law," World Trade Review Vol. 8 No. 4 (2009): 477-515. 
so far been adopted by Indonesia: UNCLOS, UNFSE, FAO Compliance Agreement (in the process), the formation of RFMO convention and its derivatives, FAO Port State Measure. There is an example of cases when Indonesian tuna was banned by Japan because Indonesia has not participated in the RFMO.

FAO report in 1992 concluded that the environmental situation is in the worst state for the past 10 years. As a result of the economic action has reached its greatest proportion, in general are; the increased degradation of natural resources, fishing business has lowered the supply marine fisheries as food, damaged in marine environmental, increasingly widespread conflict and the state of the small fishing increasingly threatened.

The report may explain some of the causes of the problems in the fisheries sector:

1) Open access fisheries sector; and

2) The operational costs that higher from income so much that needs to be subsidized.

Whereas because the majority of fishermen are still traditional, and low in technology as well as education, and inefficient fishing patterns (un-environmentalfriendly equipments, poor quality catches because the technology is still insufficient), subsidies are necessary to achieve national objectives with regard to the international provisions. So that the subsidies conducted by Indonesian government, are aimed fora better fisheries management so that fishing promotes the concept of sustainable development.

Related to the fact whether or not the current Indonesian fisheries policies regarding subsidies are prone to be challenged, depends on how the ASCM are being interpreted. As long as the subsidy did not cause market distortions then it should not be a problem. Over time there will always be the potential for accusations toward subsidies. Back to the interpretation of the ASCM, it is not uncommon for the imposition of countervailing duty on imported goods is conducted as an effort to protect a country's domestic market.

However, problems arise in determining the impact of the fisheries subsidies on fish stocks. Problems that can be identified in this matter is to determine on how the subsidies affecting the fishing system and how to track the impact of the subsidies through the system towards a point which disrupt the fish populations. To find out, the following pattern can be used: ${ }^{18}$

1. Specifications of the subsidy program;

2. Implementation of the subsidies program;

3. The stimulus given to the industry or companies that receive subsidies; and

4. The reaction of industry or company to the stimulus.

Subsidies are Indonesia's effort to achieve sustainable fisheries without compromising functions of the state to reduce poverty. Current subsidies program does not have a tendency to market distortions. However, different things happened to the concept of Sustainable Development, which is being promoted by the global community at the moment. The systems and mechanisms have not been able to accommodate the overfishing issue that is now emerging.

\footnotetext{
${ }^{18}$ Draft of Academic paper on Amendment Act No. 31 of 2004 Regarding Fisheries, p. 55.
} 


\section{Conclusion}

A fundamental legal issue of the implementation of fisheries subsidies to the implementation of fair trade is the unclear definition of fisheries subsidies. There is still an ongoing debate about the subsidies that can be done by the government. The current legislation has the potential to be defined as subsidies, both actionable and prohibited subsidy, but it still needs to be proven whether it meetsthe elements of subsidy in the ASCM. Related to the legal issues regarding the implementation of sustainable fisheries, not all of the provisions in the international regulations are being adopted by Indonesia because of several factors. However, the policy leads to the management and development in the field of fisheries, as mandated in international legal instruments, and to make national fisheries industry as one of the driving force of the Indonesian economy.

Subsidy mechanisms are implemented in Indonesia through the industrialization of environmentally friendly fishing such as ECOPORT which is now underway. However, Indonesia still needs the proper and adequate systems and mechanisms to prevent further deterioration of the current fisheries condition.The lack of an adequate supervision, resulting the difficulties on Indonesian government, especially at the port level, to continuously monitor, supervise, and if necessary, limit, fishing activities in the sea, so it is very difficult to calculate or predict and prevent overfishing.

Subsidy mechanisms in the context of fair trade are subsidies that are specifically intended for non-businesses fishing and business activities which are not in the form of limited company, particularly small fishing whose fisheries products are not intended to be exported. Government assistance programs for small fishing intended to encouraging entrepreneurship of fishing communities and expanding cruising range of fishermen. In contrast, for the fishermen which are alreadyin the form of corporation, or conducting business aiming for export, or which are not belonging to the small fishermen group, they did not receive any aid program of the Government of Indonesia.

From this research, it can be suggested that there should be a harmonization of perception and an understanding of the definition and scope of the subsidy itself. If Indonesia decides to adopt international rules on subsidies, it shall conduct alignments and socializations to the lowest level field authority to prevent differences and heterogeneity in the perception and understanding of the scope of subsidies. In addition, if the Indonesian government aids programs aim to encourage business development in the field of fisheries for non-businesses fishing and business activities which are not in the form of company, especially for small fishermen, by launching various assistance programs, then, Indonesian government should make adequate systems and mechanisms which may encourage the success of the programs.

In relation to sustainable development in the field of fisheries, particularly on the issue of overfishing, the Indonesian government must also establish a system and a strict supervision mechanism, which can be used to continuously monitor, supervise, and if necessary to restrict, fishing activities in the sea, either by repairing and improving existing systems, or by creating a new system which can accommodate the shortcomings of the existing system. 


\section{Bibliography}

\section{Books}

Basri, F. Perekonomian Indonesia; Tantangan dan Harapan Bagi Kebangkitan Ekonomi Indonesia. Jakarta: Erlangga, 2002.

Chen ,Chen-Ju. Fisheries Subsidies under International law. London: Springer, 2010.

Marry, An Palma. Et.al. Legal Aspects of Sustainable Development, Promoting Sustainable Fisheries, The International Legal \& Policy Framework to Combat Illegal, Unreported \& Unregulated Fishing. Leiden: Martinus Nijhoff, 2010.

Milazzo, Matteo. Subsidies in World of Fisheries a Reexamination. (World Bank Technical paper ; no. WTP 406. Fisheries series.) Washington, D.C. : The World Bank, 1989.

Ministry of Marine Affairs and Fisheries Republic of Indonesia. Rencana Strategis Kementerian Kelautandan Perikanan 2010-2014. Jakarta: Ministry of Marine Affairs and Fisheries Republic of Indonesia 2010.

Ragnar, Arnason. Et.al. The Sunken Billions, the Economic Justification for Fisheries Reform. Washington, DC: The World Bank, 2009.

Solihin, Akhmad. Et.al. Laut Indonesia Dalam Krisis. Green Peace, 2013.

Spenser, Milto H. And Orley M. Amos, Jr. Contemporary Economics. $8^{\text {th }}$ edition. New York: Whort Publishers, 1993.

Suparmoko, M.. Keuangan Negara dalam Teori dan Praktek. $5^{\text {th }}$ edition. Yogyakarta: BPFE, 2003.

\section{Articles}

Asche, Frank and Martin D. Smith. "Trade and Fisheries: Key Issues for the World Trade organization." (USA Staff Working Paper ERSD-2010-03 World Trade Organization Economic Research and Statistics Division January 2010).

Dewi, Galuh Prila. “Urgensi Subsidi Perikanan di Indonesia." In Peran Subsidi Terhadap Pertumbuhan Ekonomi Indonesia. Edited by Hariyadi. Jakarta: Pusat Pengkajian Pengolahan Data dan Informasi Sekretariat Jenderal DPR RI, 2010. http:// berkas.dpr.go.id/pengkajian/files/buku_tim/buku-tim-12.pdf.

Ginting, Ari Mulianta. "Analisa Kebijakan Subsidi terhadap Pertumbuhan Ekonomi Indonesia." In Peran Subsidi Terhadap Pertumbuhan Ekonomi Indonesia. Edited by Hariyadi. Jakarta: Pusat Pengkajian Pengolahan Data dan Informasi Sekretariat Jenderal DPR RI, 2010. http://berkas.dpr.go.id/pengkajian/files/ buku tim/buku-tim-12.pdf.

Lisnawati. "Proyek Implikasi Penurunan Subsidi Pupuk Terhadap Kesejahteraan Petani." In Peran Subsidi Terhadap Pertumbuhan Ekonomi Indonesia. Edited by Hariyadi. Jakarta: Pusat Pengkajian Pengolahan Data dan Informasi Sekretariat Jenderal DPR RI, 2010. http://berkas.dpr.go.id/pengkajian/files/buku tim/ buku-tim-12.pdf.

Naamin, N dan A Hardjamulia. 1980. "Potensi Pemanfaatan, dan Pengelolaan Sumber daya Perikanan." (Paper presented on Fisheries Forum I, Sukabumi, 19-20 July 1980).

Schorr, David K. "Healthy Fisheries, Sustainable Trade: Crafting New Rules on Fishing Subsidies in the World Trade Organization." (A WWF Position Paper and Technical Resource, June 2004).

Sharp, Renee and U. Rashid Sumaila. "Quantification of US Marine Fisheries Subsidies." North American Journal of Fisheries Management 29 No. 1 (2009): 18-32.

Southgate, D and M. Whitaker. "Promoting Resources Degradation in Latin America: 
Tropical Deforestation, Soil Erotion, and Coastal Ecosystem Disturbance in Ecuador." Economic Development and Cultural Change.Vol. 40. No. 4 (July 1992): 787-807.

Young, Margaret A. "Fragmentation or Interaction: The WTO, Fisheries Subsidies, and International Law." World Trade Review Vol. 8 No. 4 (2009): 477-515.

\section{Websites}

UNEP. "Analyzing the resource impact of Fisheries Subsidies: A Matrix Approach." http://www.unep.ch/etb/publications/fishiersubsidiesenvironment/ anaresimpfishsubs.pdf. Accessed on 15 March 2015.

WTO. "Introduction to fisheries subsidies in the WTO." https://www.wto.org/english/ tratop_e/rulesneg_e/fish_e/fish_intro_e.htm. Accessed 12 June 2014.

" 'Friends of Fish' Press for Negotiations on Fisheries Subsidies at WTO." http://www.ictsd.org/bridges-news/biores/news/friends-of-fish-press-fornegotiations-on-fisheries-subsides-at-wto. Accessed on 15 March 2015. 